\title{
The Wasif Jawharriyeh Collection: Illustrating Jerusalem during the First Half of the 2oth Century
}

\author{
Issam Nassar
}

This chapter briefly examines the photographic collection of the Jerusalem diarist Wasif Jawharriyeh (1897-1972), whose life in the city spanned the last two decades of Ottoman rule and the British Mandatory period in Palestine. ${ }^{1}$ In 1948 , following the fall of his neighborhood in the western suburbs of Jerusalem to Israeli control, Jawharriyeh left Palestine and ended up in Lebanon, where he passed away in 1972. Although he was a well-known figure while living in Jerusalem, he fell into oblivion until his diaries were discovered and published some thirty years after his death. ${ }^{2}$ Although his reputation as the "storyteller of Jerusalem" spread after the publication of the diary, during his time in the city, his claim to fame was his musical career as an amateur oud player. A native of Jerusalem, Jawharriyeh came from a Christian family with deep roots in the city. He was the son of Girgis Jawharriyeh, a prominent notable in the Greek Orthodox Arab community during the last few decades of Ottoman rule, and a devout administrator of the property of the Husayni family, two of whom became mayors of Jerusalem during Wasif's life.

His published memoirs span the years he spent living in Jerusalem, from as early as 1904 until his forced departure in 1948. Although he continued to record his life in diaries through the next two decades, the published version only includes his time in Jerusalem. Following publication, the Jerusalem diaries were hailed by historians as an invaluable source of insight into Jerusalem's

1 Salim Tamari, "Jerusalem's Ottoman Modernity: The Times and Lives of Wasif Jawhariyyeh," Jerusalem Quarterly, no. 9 (2000).

2 First published in Arabic in two volumes: Salim Tamari and Issam Nassar, Al-Quds al-Uthmaniyya fi al-Mudhakkirat al-Jawhariyya: al-Kitab al-Awwalmin Mudhakkirat al-Musiqi Wasif Jawhariyya, 1904-1917 [Ottoman Jerusalem in the Jawhariyyeh memoirs: the first book of the memoirs of the musician Wasif Jawhariyya, 1904-1917] (Beirut: Institute for Palestine Studies, 2003); Salim Tamari and Issam Nassar, Al-Quds al-Intidabiyya fil al-Mudhakkirat alJawhariyyeh, 1918-1948 [British Mandate Jerusalem in the Memoirs of Wasif Jawhariyyeh, 1918-1948] (Jerusalem: Institute of Jerusalem Studies, 2005). Then selections were published in English: Salim Tamari and Issam Nassar, The Storyteller of Jerusalem: The Life and Times of Wasif Jawharriyeh, 1904-1948, trans. Nada Elzeer (Northampton: Olive Branch Press, 2014).

(C) ISSAM NASSAR, 2018 | DOI:10.1163/9789004375741_024

This is an open access chapter distributed under the terms of the prevailing CC-BY-NC-ND License at the time of publication. 
social history, and have been used in a number of studies and documentary films. ${ }^{3}$ In addition to moments from his personal life, Jawharriyeh documented political events such as Jerusalem's receiving the news of the Ottoman revolt in 1908, from Istanbul, as well as the years leading to the Great War and of the war itself - including his service in the Ottoman navy in the Dead Sea, the fall of Jerusalem to the British in 1917, and life during the British Mandate. He described the social life and the fabric of the city through special occasions, festivities, cuisine, music, and art scenes. Life in Jerusalem, marked by political events and changes, is the focus of the images in the photograph albums Jawharriyeh collected. These albums are examined here as forms of archival material and show how precious this collection is for the study of the history of Jerusalem, and Palestine in general.

The archive, as embedded in the meaning of the term, combines the ideas of time, space and order. As Jacques Derrida argued, it synchronizes the principles of time, space, and authority: while time and space relate to the historical, material, and ontological, authority relates to order and power. ${ }^{4}$ Archives are collections of artifacts amassed in a certain order to serve a particular power structure. In their official archives, states collect materials that reflect how they control society, exercise their authority, and preserve their memory as institutions. Although the collected materials are classified according to certain organizational principles such as period, location, and institution, the most important principle is often the exercise of power and control. States and institutions are not the only authorities that create archives: individuals also make archives, synchronizing their own authority over time and space. When individuals collect, they may not use the term "archive" to describe their collections and may not necessarily think in archival terms. Nevertheless, the dynamics of collecting and ordering in the individual obey the same principle of the exercise of power that may be observed in the state. An individual's power, however, is governed by personal needs and desires.

Individuals collect documentary artifacts for various reasons. Some people preserve official documents needed for their survival in the legal and political structures in which they live, such as birth certificates, passports, property deeds, and educational or professional credentials. Others collect artifacts for sentimental value in their personal, familial, or communal lives. In many

3 One such film is 1913: Seeds of Conflict, produced by Ben Loeterman for PBS in 2014, and an example of a study is Rachel Beckles Wilson, Orientalism and Musical Mission: Palestine and the West (Cambridge: Cambridge University Press, 2013).

4 Jacques Derrida and Eric Prenowitz, "Archive Fever: A Freudian Impression," Diacritics 25, no. 2 (1995). 
cases, individuals build collections in order to attest to the way they regard themselves and their role in the world around them. History buffs, for example, collect documents that they deem historically significant. Music lovers and art enthusiasts do the same for the subjects that move them. No matter the nature of the collection, owners arrange elements of their archives in relation to time, place or assumed significance. In doing so, they exercise their authority and judgment on what they choose and the manner in which they assemble and order it. Although individual collections are often not of great importance to state authorities, for historians they bring to light both practices and sources for historical documentation. Historians use such materials not only as evidence of events, but as pathways through which they can construct the worldview of the periods they study. Such is the case of the albums under scrutiny here.

\section{Producing Images, Creating Albums}

The first published volume of Jawharriyeh's memoirs in Arabic includes a digital disk with some of his songs, but only a handful of images from his collection of photographs are found in the book. ${ }^{5}$ His collection of more than nine hundred images could not fit into a single publication. For this reason, the photographs were divided into seven albums designed to accompany the diary. Collecting photographs was not a common practice in Palestine at the time, though it later became popular. Photographs were expensive and rare as they were produced manually with glass or celluloid negatives. In most cases, photographers were professionals and were not easy to come by. Although the period during which Jawharriyeh's collection was assembled covers more than six decades after the invention of photography, the art was still in its infancy and only a handful of studios served the public demand. The earliest images of Jerusalem and Palestine were taken decades before, principally by nonresident European photographers whose intention was to feed the lust of European viewers for images from the Holy Land. Collecting pictures in albums was a new trend, born of the desire of tourists and pilgrims to document their voyages.

With the rise in the number of photographic studios in Jerusalem in the first two decades of the twentieth century, arranging photographs in albums gradually became a popular practice among residents, though it remained largely limited to the wealthy. Most of the earlier local albums were of a familial nature, consisting of portraits of family members and social occasions such as weddings and visits of important guests. However, with the establishment of

5 Tamari and Nassar, Al-Quds al-Intidabiyya. 
Israel, self-declared as the state of the Jewish people, a mass ethnic cleansing of the native non-Jewish population of Palestine took place. Exiles often left in a hurry, abandoning valuable items in their homes. Photographs, albums, family papers, and property deeds were often left behind in the drawers and cabinets in which they were stored. The failure to establish a Palestinian state also meant that many archival documents were lost to the people, although some survived in the archives of the various occupying powers that possessed the land before and after the mass expulsion. Jawharriyeh's albums bear witness to the years before great change, standing as documentary evidence of bygone times. They are a visual documentation of life in a liminal period in the history of the city, and they exhibit a native's perspective of it and its society.

\section{Creating Albums, Producing Archives}

The albums at hand document a life that spanned a period close to five decades, during which Jerusalem and Palestine changed hands from the large Ottoman Empire to a much smaller entity ruled by the even larger British colonial empire. This period witnessed the start of the Jewish Zionist immigration to the country and the creation of the Israeli state. These events coincided with the temporary burial of the Palestinian project of an independent state. I argue that the Jawhariyyeh albums are important because they bear witness to the loss of their original subject in a material sense, that is, Jerusalem in a time of more or less peaceful coexistence. Images from Palestine before its conquest have become foundational elements in the collective nostalgia of the Palestinians. ${ }^{6}$ The albums are chronologically organized and contain photographs of leaders, rulers, elites, and locations. Together they fueled a powerful narrative of loss and longing for homeland that was central to the identity construction of the Palestinians in exile. The collection commences in the late Ottoman period and finishes shortly before the events of 1948. Jawharriyeh kept a separate notebook for each of the albums in order to describe the photographs. In addition to the pictures themselves, these notebooks are valuable sources of information about the period. From today's standpoint, the albums can be described as records documenting the liminal period separating Ottoman rule in Palestine and the creation of the state of Israel. In this sense,

6 Elias Sanbar, ed., Jérusalem et la Palestine: le fonds photographique de l'École biblique de Jérusalem (Paris: Hazan, 2013); Sanbar, Les Palestiniens: la photographie d'une terre et de son peuple de 1839 à nos jours (Paris: Hazan, 2004); Walid Khalidi, Before Their Diaspora: A Photographic History of the Palestinians, 1867-1984 (Washington, DC: Institute for Palestine Studies, 1984). 
they function as an infusion of memories before Jawharriyeh's departure from Palestine in the aftermath of the Palestinian catastrophe of 1948. The events of that year had acquired meaning within the collective Palestinian memory, not only as references to a lost past, but also as a defining moment in the historical narrative of Palestinians.

While amassing what he referred to as the "Jawharriyeh Collection," Jawharriyeh saw himself as the guardian of Jerusalem's memory. The cover of his albums states that the collection was established in 1924, but it is unclear if the date refers to the photographic albums or the entire body of materials. The first album is devoted to the Ottoman period. In fact, he wrote in the accompanying notebook that he adorned the album with the emblem of the Ottoman state and he dedicated it to both the Ottoman sultan and the governor of Jerusalem. Dedicating a personal collection - an album in this case - to a ruler seems unusual, especially since the album was probably created at a time when the Ottoman state was no longer in existence. Such an act of dedication could serve as an indication of his intention in collecting the photographs and fashioning them in an album. It is highly unlikely that Jawharriyeh had any contact with the sultan, and chances are slim that the sultan would ever have had the opportunity to see the albums. Still, by including such a dedication, he intended to give merit to the album as a public work and showcase it as if it were a published book. The sultan to whom he dedicated the album was removed from power in 1909, when Jawharriyeh was no more than a teenager. In his own memoirs, he showed disapproval, if not outright animosity, towards this specific sultan. However, the dedication reads as follows:

I adorn this book with the emblem of the Ottoman state ... his royal majesty Sultan Abdülaziz, one of the great kings of the Ottoman state who was followed in the high position by his brother Sultan Abdülhamid, and with a photo of his Excellency Ra'uf Pasha, the mutessarif of Jerusalem.

Jawharriyeh failed to include the picture of the sultan, but he reserved an empty space for it in the album. It is very likely that he was echoing his father's admiration for the specific regime that was overthrown and replaced by one that was significantly different and perhaps had elements of an anti-Arabness that were more dominant than those of its predecessor. His father, Girgis Jawharriyeh, was a "lawyer in his younger years and stood out as a Christian lawyer at Jerusalem's Muslim shari'a law courts"7 during the period of both

7 Tamari and Nassar, The Storyteller of Jerusalem, 35. 


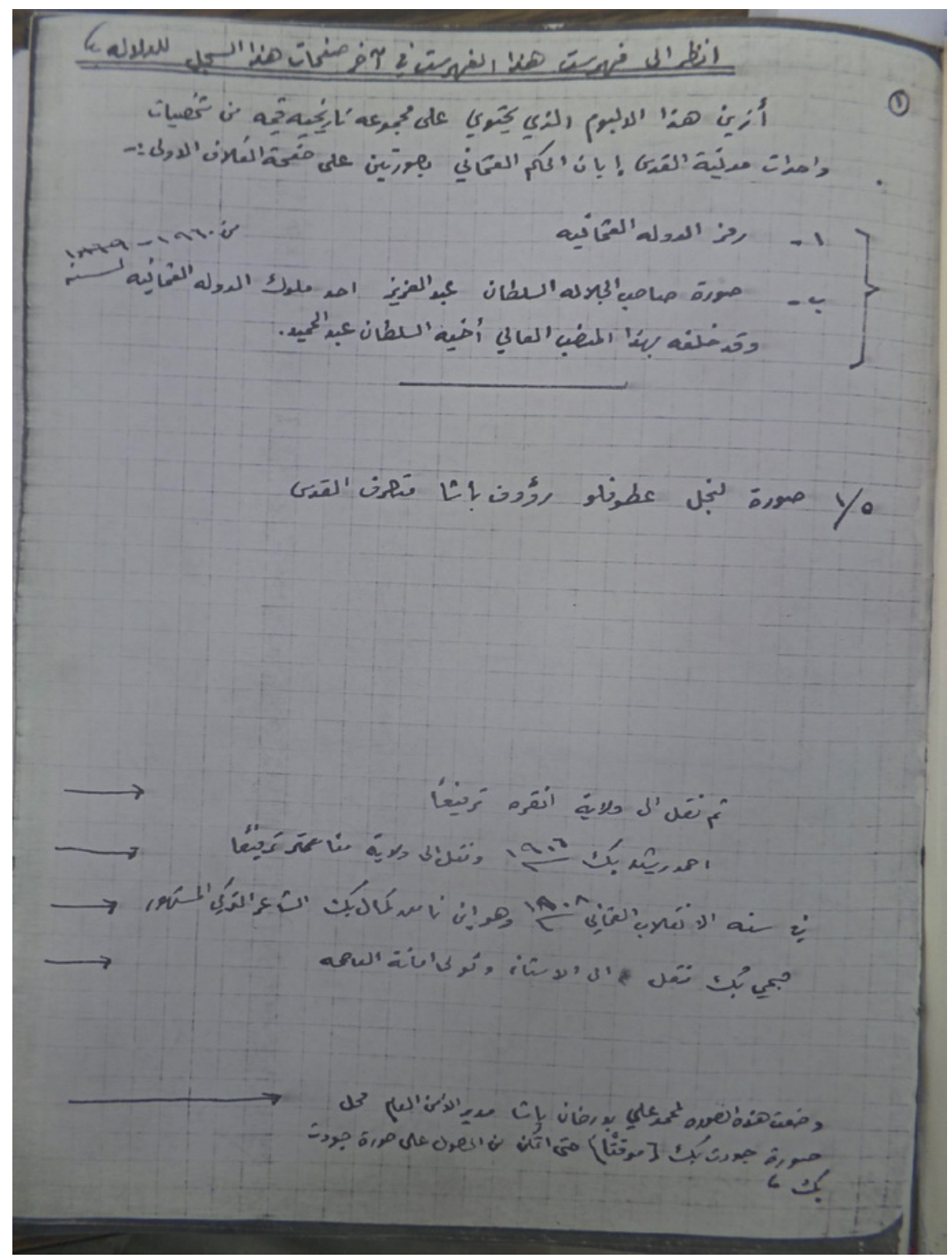

FIGURE 19.1 The page in the notebook where WasifJawharriyeh announces the inclusion of the photographs of the sultan.

JAWHARRIYEH COLLECTION. 
Sultan Abdülhamid (1876-1909) and governor Ra'uf Pasha (1877-89), whose picture appeared in the first album.

The dedication to the Ottoman sultan and the governor of Jerusalem may therefore be read as a gesture by which Jawharriyeh wished to honor his father rather than reflect his own politics. Indeed, based on his writings, Jawharriyeh appears to have been an opponent of the Hamidian regime. Another possible explanation for the dedication is that he wanted to reflect the dominant discourse of the periods he was documenting. Photographs of other authority figures included in his albums lend support to this explanation. There is, for example, a photograph of Jamal Pasha, the head of the fourth Ottoman army in Palestine during the Great War, who is often referred to in the memoirs as "the butcher." ${ }^{8}$ Other photos include British governors and high commissioners, whom Jawharriyeh also opposed, considering them as enablers of the Zionist colonization in Palestine.

Although Jawharriyeh fails to provide the names of the photographers or the individual sources for each of the photographs he inserted in his album, he does mention in his notebooks how he came to acquire the pictures:

I was able, thank God, to collect the rare and historical pictures from a number of individuals, for whose affection I am indebted, such as Sheikh Khalil al-Khalidi, Ahmad Sameh al-Khalidi, Ismail Bek al-Husseini, Ragheb al-Nashashibi, Beshara Habib and others. May God rest their souls.

The names above are those of some of the most important notables of Jerusalem at the time. Mentioning them serves Jawharriyeh well in placing himself as a member, or at least an acquaintance, of the city's elites. The above note refers to the portrait photographs that he placed at the beginning of the first album, rather than to photos in the album that were public in nature, such as events, processions, and locations that would have been obtained at any of the tourist shops in the city. The sheer number of portraits of notables, Ottoman officials, governors, city mayors, and members of the Greek Orthodox clergy that Jawharriyeh included in the album, constitute an important and unique visual archive. The second half of the album is devoted to the Great War in Palestine. Photographs include a number of portraits of Ottoman officers and leaders, including Jamal Pasha. Most of the images can be traced to two photographic collections, those of John Whiting of the American Colony Photo Department, ${ }^{9}$

8 Ibid., 199.

9 Partially accessible here http://www.loc.gov/pictures/collection/matpc/colony.html\# department. 


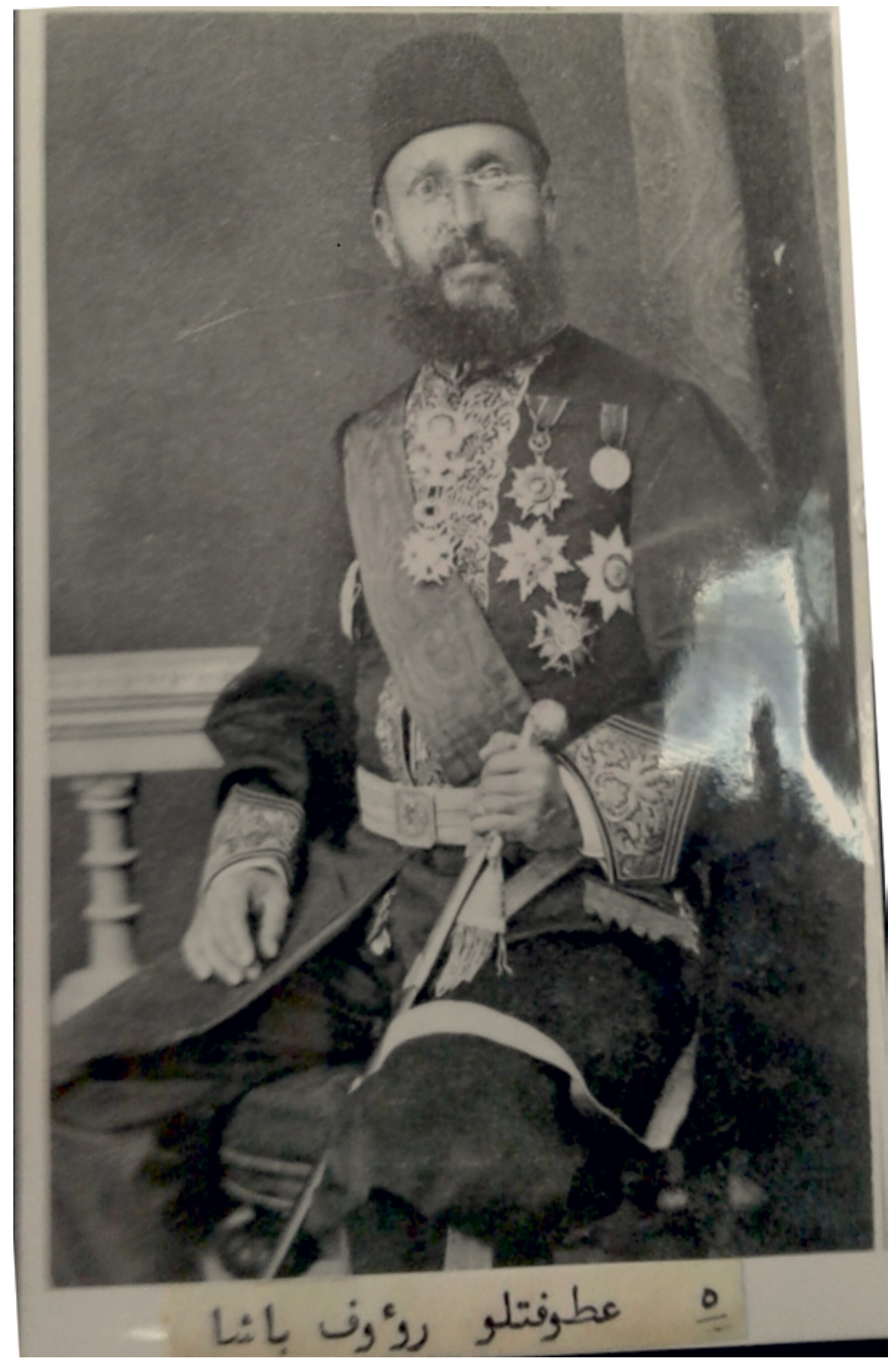

FIGURE 19.2 Ra'uf Pasha, the mutessarif of Jerusalem, as he appeared in the first album.

JAWHARRIYEH COLLECTION. 
and the Arab photographer Khalil Ra'ad. ${ }^{10}$ Both photographers were employed at points to document the Ottoman war effort in southern Palestine and the Sinai Peninsula. However, like elsewhere, Jawharriyeh failed to credit the photographers. This may be understood as an indication of his disinterest in the pictures in themselves as artifacts, but may also be interpreted in terms of his interest in the individuals photographed. It is very likely in this case that the images were bought by Jawharriyeh directly from the shops in Jerusalem's Jaffa Gate.

In the section on the war, the photographs he includes illustrate the lives of the Ottoman soldiers at various locations. Jawharriyeh himself was conscripted into the Ottoman navy in the Dead Sea, but the album lacks any images from that location. There are a few pictures of Jerusalem during World War I, including an image of the hanging of a deserter outside the Jaffa Gate. Khalil Ra'ad, whose studio was located across the street from where the hanging took place, was the photographer.

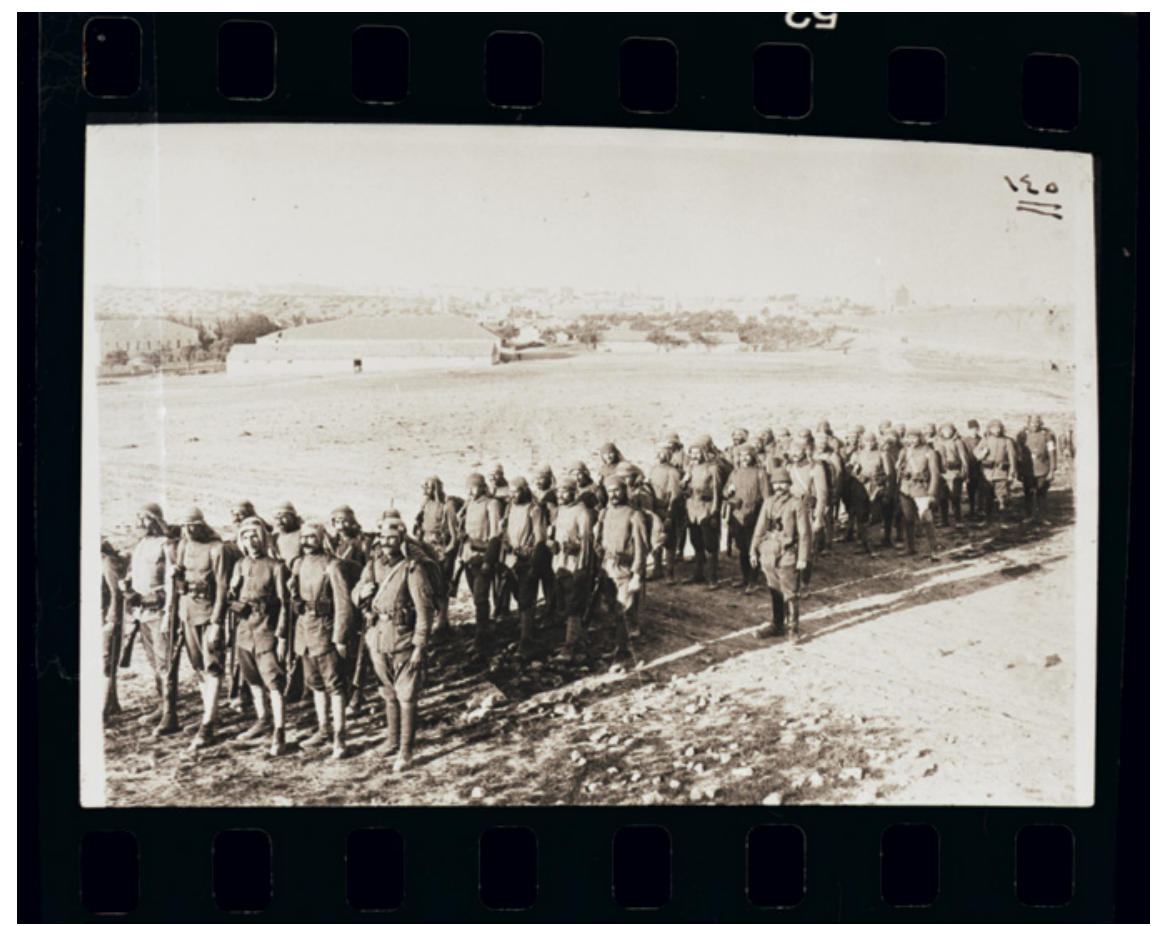

FIGURE 19.3 Ottoman troops in Palestine.

JAWHARRIYEH COLLECTION.

Khalidi, Before Their Diaspora. 
Jawharriyeh presented his albums as historical records of the times more than as a reflection of his personal feelings, or the ties he might have had with the leaders whose photographs adorned his albums. The figures he featured in his albums always appeared at their best, posed in formal portraits and exuding an aura of authority, rather than in images that showed them behaving ruthlessly, as in the case of the images of Jamal Pasha, who is referred to in the memoirs as "al-Safah" (the butcher). His album of the Ottoman period ends with a famous photograph showing the surrender of Jerusalem to the British forces on December 9, 1917, in which the mayor of the city and his entourage posed with the white flag of surrender next to the two soldiers they encountered on that day. Taken by Lars Larson, a photographer from the American Colony group in Jerusalem, this image has appeared in numerous publications with various captions usually providing the names of the two British officers. In this sense, it is a fortuitous example of simultaneous, nonintersecting histories in which the people of the city are often left out. While Jawharriyeh failed to mention the names of the two officers, he listed the names of everyone else present, in his caption; he even described where he was at the time of the event, despite not featuring in the photograph whatsoever. By inserting himself into the story, he was, in fact, exercising his authority as an archivist and narrator. In his memoirs, he wrote:

On this day, my brother Khalil, my mother, my brother Fakhri, and I were at my sister Afifeh's home on the western side of Saint Julian Street. I recall that on that day all Christian denominations rang their church bells to celebrate this happy occasion and held services in their churches. After Hussein Bey al-Husseini officially surrendered the city, the American Colony in Jerusalem published a photograph of historic value, which I have kept in the Jawharriyeh Collection. ${ }^{11}$

Jawharriyeh was not present at the surrender event, but he kept a picture of it in his collection. As the selection above from the memoirs shows, he witnessed the event from a distance through the ringing of the church bells. By keeping the photograph in his collection, as well as narrating the event in his diary, he managed to insert himself into the event as a witness. He recalls in some detail what he and others in his family were doing at the exact time of the surrender. Though it was a mundane day for Jawharriyeh on a personal level, it was a significant moment in history. He inserted himself into an event of great 
historical significance through exercising the power to fashion time and place such that the surrender of the city occurred when he was visiting his sister, rather than when the British won the battle or when the Ottomans withdrew, or at any other possible objective historical reference point.

Jawharriyeh, again, failed to credit the photographer of the image of the surrender. With the exception of some of the portraits, he rarely referred to the ways he came to acquire the pictures. The failure to name the photographer stands in contrast to the careful documentation that accompanied his memoirs. To him, the connection with the subject of the picture is more important than the photograph itself or its author.

The albums also include photographs of religious processions in Jerusalem. This is in line with the descriptions of such festivities that appeared in the published memoirs.

Still, unlike the memoirs in which the festivities of all religions are described - Jewish, Christian, and Muslim - the majority of the photos in the

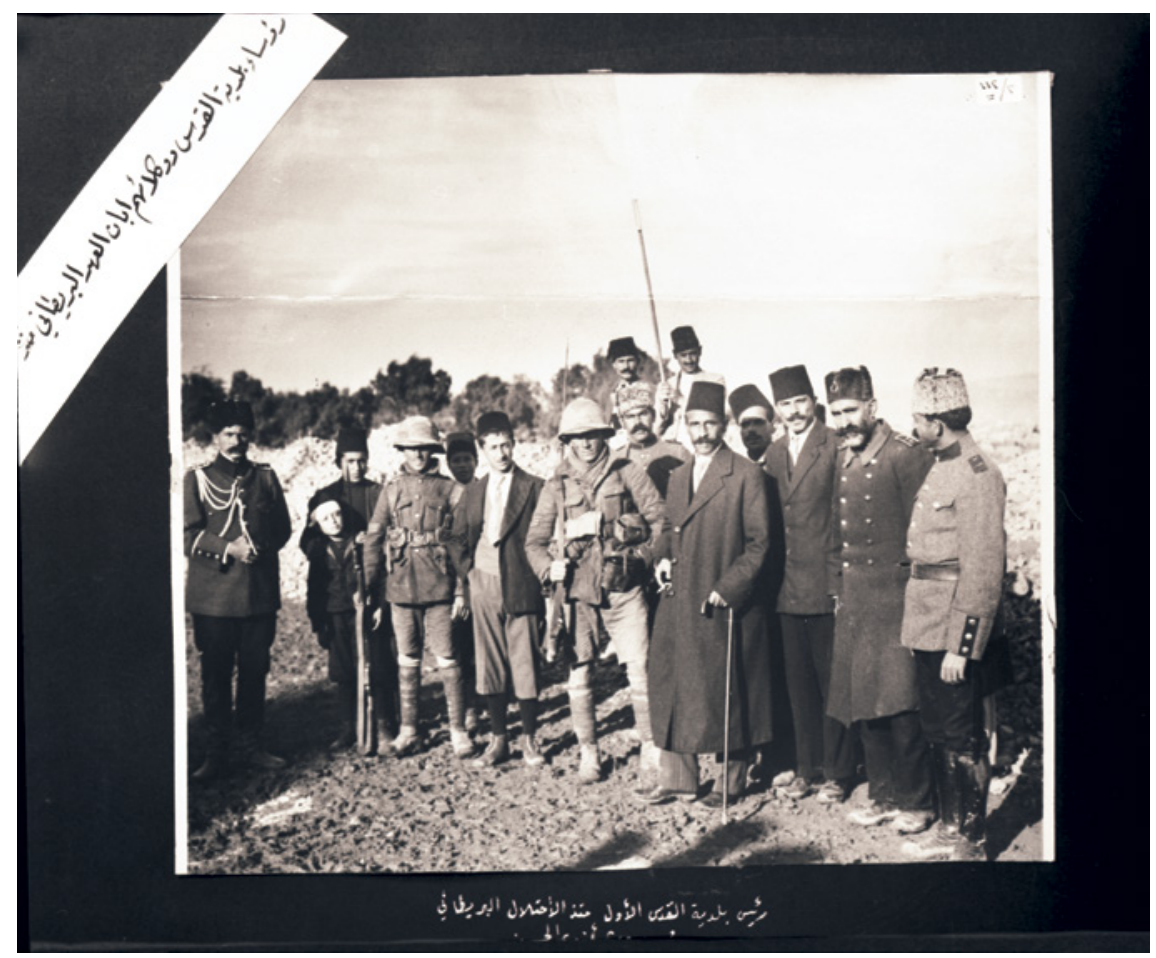

FIGURE 19.4 The mayor's entourage upon the surrender of Jerusalem, December 1917. JAWHARRIYEH COLLECTION. 


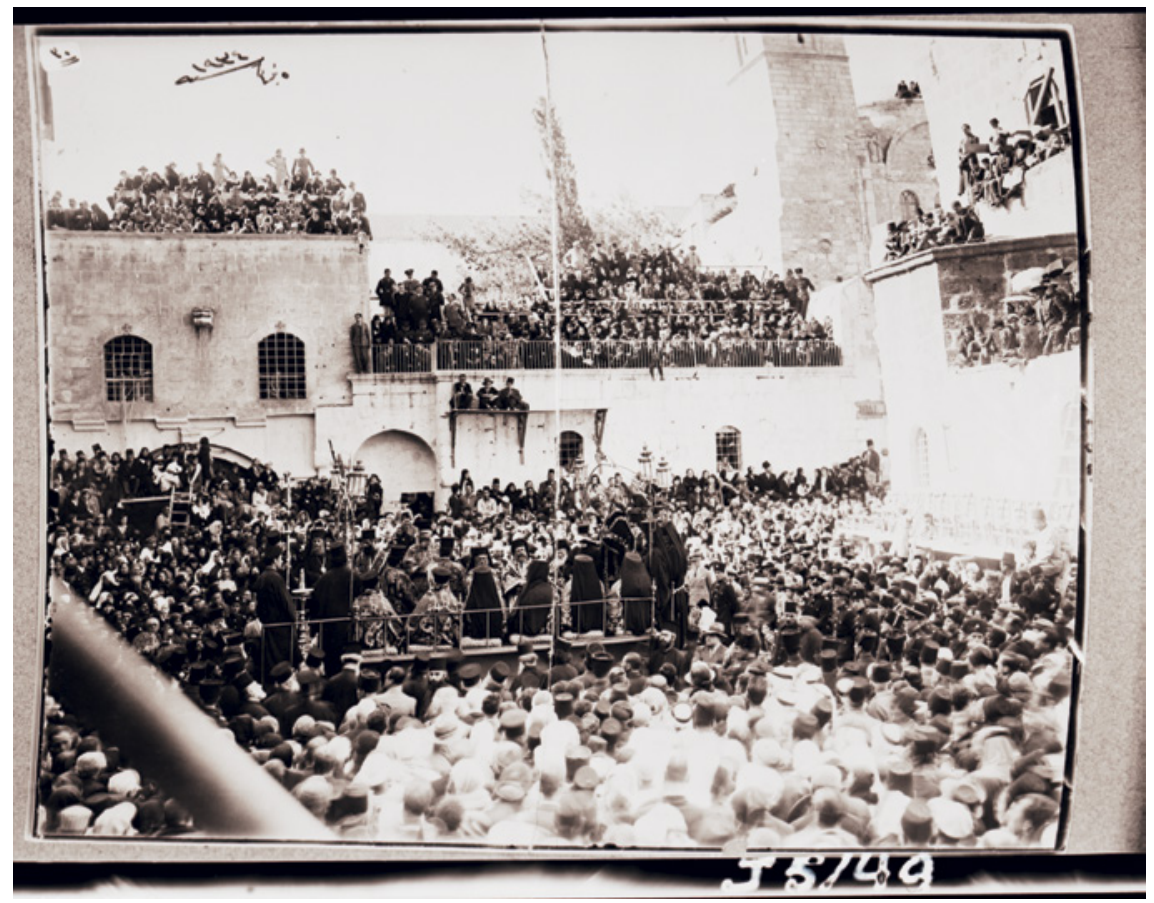

FIGURE 19.5 The procession of the patriarch leaving the Church of the Holy Sepulchre. JAWHARRIYEH COLLECTION.

albums seem to represent Christian, and particularly Orthodox processions, though a few images of the Muslim festival of Nabi Musa were included. ${ }^{12}$

As a member of the Greek Orthodox community with strong ties to Patriarch Damianos, who is mentioned several times in the memoirs, Jawharriyeh devoted an entire section in the first album to the Orthodox clergy in the city. ${ }^{13}$

12 Roger Friedland and Richard Hecht, "The Nebi Musa Pilgrimage and the Origins of Palestinian Nationalism," in Pilgrims and Travelers to the Holy Land, ed. Bryan F. Le Beau and Menachem Mor (Omaha: Creighton University Press, 1996); Kamal al-'Asali, Mawsim al-Nabi Musa fî Filastin: Tarikh al-mawsim wa-l-maqam [The mawsim of Nabi Musa in Palestine: History of the mawsim and the sanctuary] (Amman: Matba'a al-Jami'a alUrduniyya, 1990).

13 Damianos I (July 10, 1848-August 14, 1931) was the Greek Orthodox Patriarch of Jerusalem from 1897 to 1931. See also Konstantinos Papastathis' chapter, "Diplomacy, Communal Politics and Religious Property Management:The Case of the Greek Orthodox Patriarchate of Jerusalem in the Early Mandate Period," in this volume. 
The album includes fifteen pictures of the various priests of the city as well as a number of images of what he described in his notebook as "the Arab men of the Patriarchate of Jerusalem." This part on the Orthodox men and priests directly follows a long section on the notables of the city, which included images of mayors, judges, writers, local members of the Ottoman administration, and others. Although in the second album we find similar photographs of the British administrators of the city, the collection in the first album is very significant as it constitutes an archive not found anywhere else. All of the photographs of the "elites" are studio portraits, which makes the photographed subjects appear at their best, in an authoritative manner, corresponding to how Jawharriyeh represented them in his diaries.

In the second album, we find an entire section devoted to the bloody events of 1929 in Palestine, when riots and clashes between Jews and Muslims broke out at the Wailing Wall. The clashes spread to the nearby city of Hebron, where a massacre of Jewish residents took place. The albums document the aftermath of the massacre. This is an interesting addition that further enhances the significance of the collection, as Jawharriyeh documents the loss of Jewish life at the hands of his fellow Arabs of Palestine. Still, in the memoirs, Jawhariyyeh decries Vladimir Jabotinsky's faction as being responsible for the riots that led to the massacres: ${ }^{14}$

The Revisionist Zionist Party, led by Vladimir Jabotinsky, began to actively call Jews to arm and resort to force, and publicly demanded the takeover of the Wailing Wall in al-Buraq. ${ }^{15}$

Another important section that runs through the albums, particularly the second album, is devoted to the visits of Egyptian, Syrian, and Lebanese artists, singers, and musicians to Jerusalem. In the albums, we find pictures of famous artists such as the dancers Tahiya Carioca and Badia Massabni, singers Farid al-Atrash, Amin Hassanayn, violin player Sami al-Shawa, and comedian Ali alKassar. While some of these pictures resemble portraits usually given to fans by artists, others were clearly taken in Jerusalem and show the visitors with their hosts. In some instances, a written dedication to Jawharriyeh appears on the pictures, as in the case of Sami al-Shawa, who, according to Jawharriyeh,

14 Ze'ev (Vladimir) Jabotinsky was a revisionist Zionist leader in Palestine who emigrated from Russia and formed a number of militant paramilitary groups, including the infamous Irgun organization.

Tamari and Nassar, The Storyteller of Jerusalem, 202. 


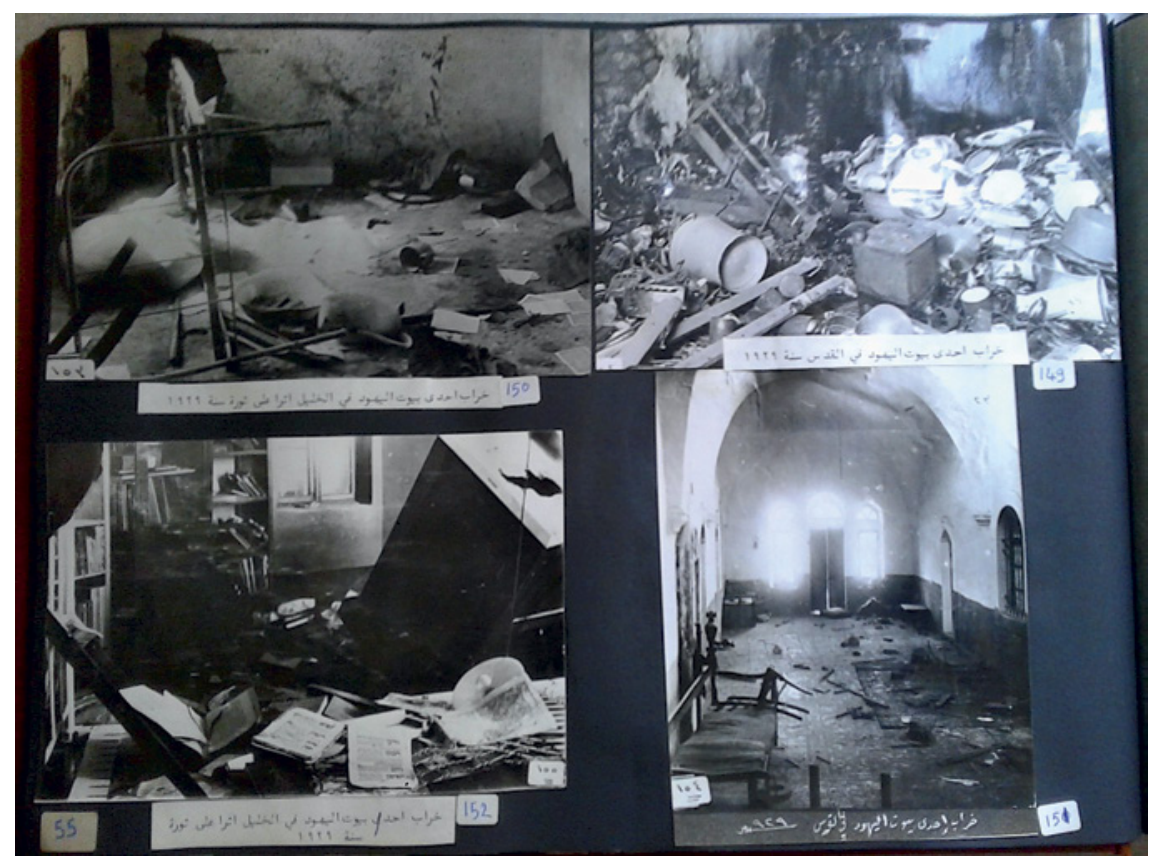

FIGURE 19.6 Page from the album showing the destruction of Jewish homes in Hebron and Jerusalem in 1929.

JAWHARRIYEH COLLECTION.

became a close friend and a frequent visitor to Jerusalem. Al-Shawa became "like a member of the Jawharriyeh family," Jawharriyeh wrote in his memoir. "Whenever he was in Jerusalem, he would stay with us, as though he was one of us." 16

\section{Conclusion}

It is not possible in this short chapter to fully account for the content of the albums; further scholarship will be needed to pursue the topic. However, it is worth noting that Wasif Jawharriyeh's provide a valuable and voluminous visual archive about Jerusalem and its history. In addition to what has been detailed above, they include images of markets, celebrations, riots, troops and many social activities. To do the collection in this study justice, it would be

16 Ibid., 180. 


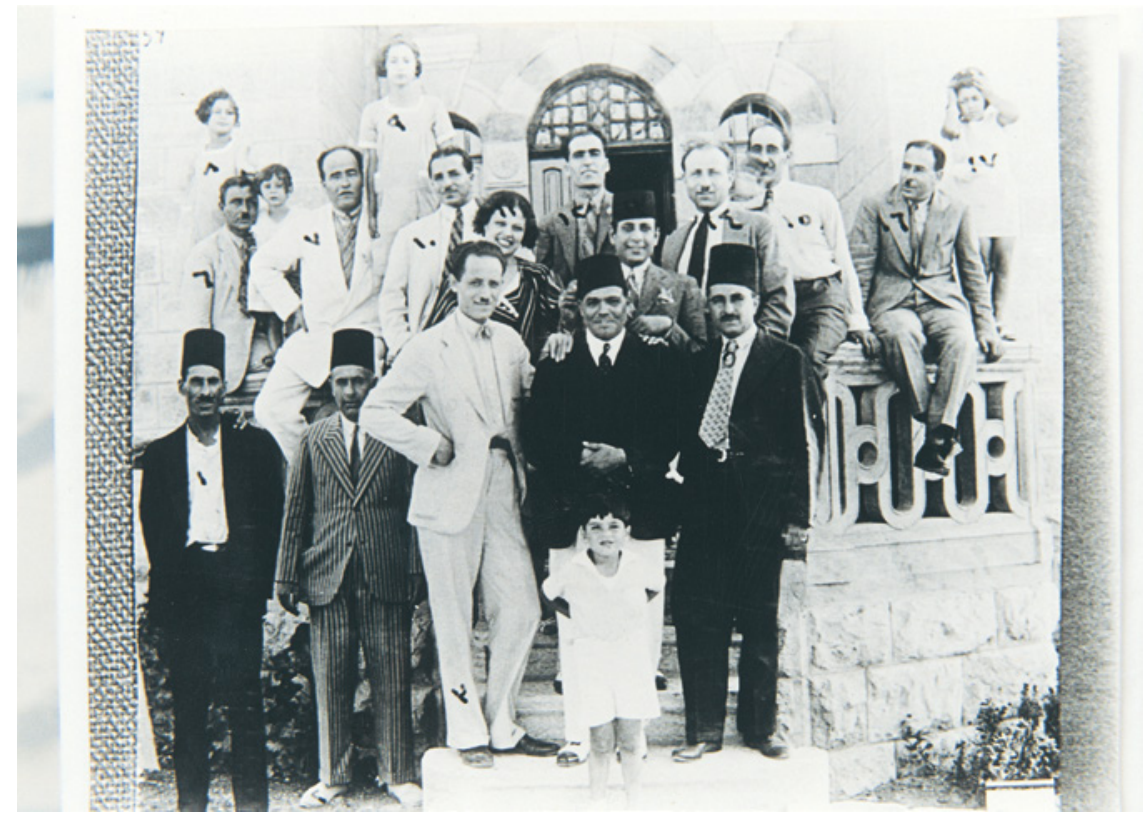

FIGURE 19.7 Visit of Ali al-Kassar to Jerusalem. JAWHARRIYEH COLLECTION.

necessary to provide a description and analysis of each and every one of the more than nine hundred images included in the collection, a task that goes beyond the scope of this contribution. Nevertheless, this introduction will acquaint the reader with the albums and their scope. What makes this collection so valuable is not only its archival nature in terms of photographs, but also the narrative that holds it together: in other words, that which makes it Jawharriyeh's story of Jerusalem. The fact that personal pictures are rare in the collection only adds to its value as an archive of the city, and perhaps as a testimony of the collector to his role as a self-declared chronicler of the city. One might speculate that Jawharriyeh was himself in the pictures through his consistent and apparently intentional absence. In leaving himself out of the images, he not only suggested how we should view him in the context of the city's social order - that is, as someone who was close to the leaders and notables - but also, as a gauge of what was significant. 